Falah, et al/Jurnal Ekonomi Syariah Teori dan Terapan Vol. 6 No. 6 Juni 2019: 1166-1177; ANALISIS PERBANDINGAN KINERJA PEMBIAYAAN BANK UMUM SYARIAH DAN BANK UMUM KONVENSIONAL DI INDONESIA PERIODE 2014-2017

\title{
ANALISIS PERBANDINGAN KINERJA PEMBIAYAAN BANK UMUM SYARIAH DAN BANK UMUM KONVENSIONAL DI INDONESIA PERIODE 2014-20171
}

\author{
Najammudin Syah Falah \\ Departemen Ekonomi Syariah-Fakultas Ekonomi dan Bisnis-Universitas Airlangga \\ Email: nsfalah14@gmail.com \\ Dina Fitrisia Septiarini \\ Departemen Ekonomi Syariah-Fakultas Ekonomi dan Bisnis-Universitas Airlangga \\ Email: dinafitrisia@gmail.com
}

\begin{abstract}
:
Banks are institutions that have the main function as recipients and distributors of funds from the public. Funds obtained can be allocated to a variety of economic sectors and the entire area that is needed in a timely and rapid manner in the form of financing. in Indonesia there are two types of commercial banks, Islamic commercial banks and conventional commercial banks. This study aims to compare the performance of sharia commercial banks and conventional commercial banks based on NPF / NPL and FDR / LDR using the sample T-test method. The results showed that there were no significant differences in the financing performance of Islamic commercial banks and conventional commercial banks.
\end{abstract}

Keywords : Kinerja Pembiayaan, Non Performing Financing (NPF), Non Performing Loan (NPL), Financing to Deposit Ratio (FDR), Loan to Deposit Ratio (LDR)

I. PENDAHULUAN

Perekonomian di Indonesia sekarang mulai berkembang pesat. Dengan adanya bank yang berfungsi sebagai Financial Intermediary, lembaga yang mempunyai peran sebagai perantara keuangan antara pihak yang memiliki kelebihan dana dengan pihak yang memerlukan dana. Menurut UU No. 7 Tahun 1992 tentang perbankan telah diubah menjadi UU No. 10 Tahun 1998 yang menyatakan bahwa Bank adalah badan usaha yang menghimpun dana dari masyarakat dalam bentuk simpanan dan menyalurkannya kepada masyarakat dalam bentuk kredit dan atau bentukbentuk lainnya dalam rangka meningkatkan taraf hidup masyarakat banyak.

Sistem lembaga keuangan bank umum di Indonesia ada dua jenis, yaitu bank dengan sistem konvensional dan bank dengan sistem syariah. Bank konvensional adalah bank umum yang melakukan kegiatan usahanya secara konvensional, sedangkan bank syariah adalah bank umum yang melakukan kegiatan usahanya berdasarkan prinsip syariah. Dalam sistem perbankan, antara bank konvensional dengan bank syariah terdapat beberapa perbedaan pada pengembalian dan pembagian keuntungan yang diberikan oleh nasabah kepada lembaga keuangan atau yang

\footnotetext{
${ }^{1}$ Jurnal ini merupakan bagian dari skripsi Najammudin Syah Falah, NIM: 041411431132 , yang diuji pada tanggal 17 Januari 2019.
} 
Falah, et al/Jurnal Ekonomi Syariah Teori dan Terapan Vol. 6 No. 6 Juni 2019: 1166-1177; ANALISIS PERBANDINGAN KINERJA PEMBIAYAAN BANK UMUM SYARIAH DAN BANK UMUM KONVENSIONAL DI INDONESIA PERIODE 2014-2017

diberikan oleh lembaga keuangan kepada nasabah (Rindawati, 2007).

Di Indonesia, bank konvensioanal telah ada sejak zaman Hindia Belanda. Sementara inisiatif pendirian bank Islam di Indonesia dimulai pada tahun 1980, dan berdirinya bank syariah pertama di Indonesia pada tanggal 1 Mei 1992, yaitu Bank Muamalat Indonesia (BMI). Pada awal masa operasinya, bank syariah belum mendapat perhatian yang optimal dalam tatanan sektor perbankan nasional. Landasan hukum bank syariah saat itu hanya diakomodir UU No. 7 Tahun 1992 tentang bank dengan sistem bagi hasil, tanpa rincian landasan hukum syariah serta jenis usaha yang diperbolehkan. Puncak masalah moneter yang terjadi pada tahun 1998 menjadi titik balik bagi bank syariah. Banyaknya bank-bank konvensional yang mengalami kebangkrutan karena terjadinya negative spread yaitu pendapatan bunga negatif, padahal pendapatan bunga merupakan sumber pendapatan terbesar bank konvensional yang dalam situasi normal di Indonesia mencakup $65 \%-80 \%$ dari total pendapatan. (Atmodjo, 1999:4). Hal ini menyebabkan beban bank terlalu besar. Akan tetapi bagi bank syariah dengan sistem bagi hasil sebagai alternatif pengganti dari penerapan sistem bunga ternyata dinilai telah berhasil menghindarkan dampak negatif dari penerapan bunga, seperti (1) Pembebanan pada nasabah berlebih- lebihan dengan beban bunga berbunga (compound interest) bagi nasabah yang tidak mampu membayar pada saat jatuh temponya; (2) Timbulnya pemerasan (eksploitas) yang kuat terhadap yang lemah; (3) Terjadinya konsentrasi kekuatan ekonomi ditangan kelompok elit, para bankir dan pemilk modal, (4) Kurangnya peluang bagi kekuatan ekonomi lemah/ bawah untuk mengembangkan potensi usaha. (Sudarsono, 2003:67).

Dengan melihat ketahanannya, pemerintah mulai memberikan perhatian lebih terhadap bank syariah. Pemerintah dan Dewan Perwakilan Rakyat menyempurnakan UU No. 7 Tahun 1992 menjadi UU No. 10 Tahun 1998 yang secara tegas menjelaskan terdapat dua sistem yang ada dalam perbankan di Indoesia, yaitu sistem perbankan konvensional dan sistem perbankan syariah. Sejak saat itu mulai banyak bermunculan bank-bank syariah di Indonesia dan perkembangannya semakin pesat dengan adanya undangundang yang mendukung kegiatan atau produk bank syariah. Salah satunya UU No 21 Tahun 2008 tentang Perbankan Syariah. BUS dalam waktu yang relatif singkat menunjukkan perkembangan dan eksistensinya di dalam perekonomian global. Masyarakat menganggap BUS dapat menjadi solusi untuk mengatasi krisis ekonomi yang terjadi. Hal ini dikarenakan BUS tidak menggunakan bunga pada sistem pembiayaannya melainkan bagi hasil. Produk pembiayaan yang 
Falah, et al/Jurnal Ekonomi Syariah Teori dan Terapan Vol. 6 No. 6 Juni 2019: 1166-1177; ANALISIS PERBANDINGAN KINERJA PEMBIAYAAN BANK UMUM SYARIAH DAN BANK UMUM KONVENSIONAL DI INDONESIA PERIODE 2014-2017

merupakan andalan dari bank syariah diharapkan dapat menjadi ujung tombak kemajuan BUS. Sistem bagi hasil merupakan daya tarik bagi pengusaha dalam menjalankan bisnisnya. Sehingga diharapkan BUS dapat menjangkau seluruh kalangan pengusaha khususnya kaum muslim. Kegiatan operasional bank konvensional menggunakan bunga sebagai alat memperoleh pendapatan maupun membebankan bunga atas penggunaan dana dan pinjaman. Sedangkan bank syariah menggunakan prinsip bagi hasil (profit and loss sharing) dan tidak terdapat bunga pada sistem operasionalnya. Akan tetapi jumlah pembiayaan BUS di Indonesia masih jauh dibanding BUK, faktor utama adalah keberadaannya yang masihs sedikit. Menurut data Otoritas Jasa Keuangan (OJK) jumlah BUS pada 2018 terdapat 13 bank sedangkan BUK terdapat 115 bank. Jumlah pembiayaan BUS dan BUK di Indonesia dapat dilihat pada tabel berikut.

Tabel 1.

Jumlah Pembiayaan BUS dan BUK di Indonesia Periode 2014- 2017

(nominal dalam miliar)

\begin{tabular}{|l|l|l|l|l|l|l|l|}
\hline \multicolumn{3}{|l|}{ BUS } & \multicolumn{4}{|l|}{ BANK UMUM KONVENSIONAL } \\
\hline 2014 & 2015 & 2016 & 2017 & 2014 & 2015 & 2016 & 2017 \\
\hline 199, & 154, & 178, & 190, & 5,468 & 5,952 & 6,570 & 7,177 \\
330 & 527 & 043 & 445 &, 910 &, 279 &, 903 &, 051 \\
\hline
\end{tabular}

Sumber: Otoritas Jasa Keuangan (OJK). 2018. Statistik Perbankan Syariah

Dari tabel 1 di atas, dapat dilihat bahwa pembiayaan pada BUS sempat mengalami penurunan pada tahun 2014 ke 2015 sebelum kembali meningkat pada tahun selanjutnya. Sedangkan bank umum konvensional selalu mengalami kenaikan pada tiap tahun.

Dari sinilah perlu adanya pengamatan untuk melihat bagaimana kinerja pembiayaan dari BUS dan BUK agar diketahui apakah sistem perbankan syariah memiliki kinerja pembiayaan lebih baik atau tidak, sehingga diharapkan BUS dapat mengevaluasi serta meningkatkan kinerjanya. Maka, dari penelitian ini penulis berusaha agar BUS dapat berkembang lebih pesat khususnya pada produk pembiyaan syariah.

Berdasarkan latar belakang yang telah dijelaskan, maka rumusan masalah dalam penelitian ini adalah:

Apakah terdapat perbedaan kinerja pembiayaan antara Bank Umum Syariah dan Bank Umum Konvensional?

II. LANDASAN TEORI

Bank

Perbankan sebagai lembaga yangmelaksanakan fungsi utama yaitu menerima simpanan vang, meminjam vang dan memberikan layanan jasa perbankan. Banyak bankir dan pakar mendeinisikan tentang bank yang berbeda, namun pada dasarnya sepakat mengatakan bahwa bank sebagai badan usaha yang kegiatan utamanya menerima simpanan dari masyarakat dan kemudian mengalokasikan kembali untuk memperoleh keuntungan serta menyediakan jasa-jasa dalam lalu lintas pembayaran. 
Falah, et al/Jurnal Ekonomi Syariah Teori dan Terapan Vol. 6 No. 6 Juni 2019: 1166-1177; ANALISIS PERBANDINGAN KINERJA PEMBIAYAAN BANK UMUM SYARIAH DAN BANK UMUM KONVENSIONAL DI INDONESIA PERIODE 2014-2017

Menurut Crosse dan Hemple (2013:22) bank adalah organisasi menggabungkan usaha manusia dan sumber pendanaan keuangan untuk melaksanakan fungsi bank yang bertujuan melayani kebutuhan masyarakat dan agar memperoleh keuntungan bagi pemilik. Sedangkan UU No. 7 Tahun 1992 tentang perbankan telah diubah menjadi UU No. 10 Tahun 1998 yang menyatakan bahwa Bank adalah badan usaha yang menghimpun dana dari masyarakat dalam bentuk simpanan dan menyalurkannya kepada masyarakat dalam bentuk kredit dan atau bentukbentuk lainnya dalam rangka meningkatkan taraf hidup masyarakat banyak. Terdapat dua jenis bank umum di Indonesia, yaitu Bank Umum Syariah (BUS) dan Bank Umum Konvensional (BUK).

\section{Bank Umum Syariah}

Bank syariah adalah bank yang aktivitasnya menghindari akan masalah riba. Dengan demikian, dalam dunia islam terkait bunga bank yang dianggap riba sangat di hindari. Perbankan syariah didirikan didasarkan pada alasan filosofis maupun praktik. Alasan filosofisnya adalah terdapat larangan riba dalam transaksi keuangan maupun non keuangan.

Dalam UU No. 21 tahun 2008 mengenai Perbankan Syariah mengemukakan pengertian perbankan syariah dan pengertian bank syariah. Perbankan Syariah yaitu segala sesuatu yang menyangkut bank syariah dan unit usaha syariah, mencakup kelembagaan, mencakup kegiatan usaha, serta tata cara dan proses di dalam melaksanakan kegiatan usahanya. Bank Syariah adalah bank yang menjalankan kegiatan usahanya dengan didasarkan pada prisnsip syariah dan menurut jenisnya bank syariah terdiri dari BUS (Bank Umum Syariah), UUS (Unit Usaha Syariah) dan BPRS (Bank Pembiayaan Rakyat Syariah) (www.ojk.go.id).

\section{Bank Umum Konvensional}

Perbankan Indonesia dalam menjalankan fungsinya berasaskan prinsip kehati-hatian. Fungsi utama perbankan Indonesia adalah sebagai penghimpun dan penyalur dana masyarakat serta bertujuan untuk menunjang pelaksanaan pembangunan nasional dalam rangka meningkatkan pemerataan pembangunan dan hasil-hasilnya, pertumbuhan ekonomi dan stabilitas nasional, kearah peningkatan taraf hidup rakyat banyak. (www.bi.go.id)

Bank Umum Konvensional (BUK) dalam praktiknya menggunakan bunga dalam transaksinya. Bunga ini yang dijadikan BUK dalam mendapatkan pendapatan bank.

\section{Pembiayaan dalam BUS}

Pembiayaan merupakan aktivitas bank atau lembaga lain dalam menyalurkan dana kepada pihak lain. Menurut Ridwan (2005:163) Pembiayaan sering digunakan untuk menunjukan aktivitas utama BMT karena berhubungan dengan rencana memperoleh pendapatan. Kasmir (2008:96) mengatakan pembiayaan adalah 
Falah, et al/Jurnal Ekonomi Syariah Teori dan Terapan Vol. 6 No. 6 Juni 2019: 1166-1177; ANALISIS PERBANDINGAN KINERJA PEMBIAYAAN BANK UMUM SYARIAH DAN BANK UMUM KONVENSIONAL DI INDONESIA PERIODE 2014-2017

penyedia uang atau tagihan yang dipersamakan dengan itu berdasarkan persetujuan atau kesepakatan antar bank dengan pihak lain yang mewajibkan pihak yang dibiayai untuk mengembalikan uang atau tagihan tersebut setelah jangka waktu tertentu dengan imbalan atau bagi hasil. Berdasarkan UU No. 7 Tahun 1992 yang dimaksud pembiayaan adalah penyediaan uang atau tagihan yang dapat dipersamakan dengan itu berdasarkan tujuan atau kesepakatan pinjam meminjam antara bank dengan pihak lain yang mewajibkan pihak peminjam untuk melunasi hutangnya setelah jangka waktu tertentu ditambah dengan jumlah bunga, imbalan atau pembagian hasil.

\section{Kredit dalam BUK}

Menurut Mulyono (2002:12) kredit adalah penyerahan uang atau tagihan berdasarkan kesepakatan pinjam meminjam antara bank dengan pihak lain yang membutuhkan dengan mewajibkan peminjam untuk melunasi hutangnya dengan bunga atau pembagian hasil keuntungan dalam jangka waktu yang sudah ditentukan.

Unsur-unsur yang terkandung dalam pemberian kredit menurut Kasmir (2011:103) adalah sebagai berikut :

a. Kepercayaan, yaitu keyakinan bagi pemberi kredit bahwa kredit yang diberikan benar-benar diterima kembali di masa yang akan datang sesuai jangka waktu yang ditentukan b. Kesepakatan, ini ditentukan dalam perjanjian dimana masing-masing pihak menandatangani hak dan kewajiban masing-masing.

C. Jangka waktu, maksudnya kredit yang diberikan memiliki jangka waktu pengembalian kredit yang telah disepakati.

d. Risiko, diakibatkan pemberian kredit yang macet atau tidak tertagih.

e. Balas jasa, bagi bank ini merupakan keuntungan atau pendapatan atas pemberian kredit yang dikenal sebagai bunga.

\section{Kinerja Pembiayaan}

Kinerja adalah keadaan yang berkaitan dengan keberhasilan organisasi dalam menjalankan tugasnya yang dapat diukur dari tingkat produktivitas, kualitas layanan, responsivitas, responsibilitas dan akuntabilitas (Tangkilisan, 2005:178). Sedangkan Wibowo (2007:7) menyebutkan bahwa kinerja berarti hasil pekerjaan atau prestasi kerja. Kinerja adalah keluaran yang dihasilkan oleh fungsi-fungsi atau indikator-indikator suatu pekerjaan atau suatu profesi dalam waktu tertentu.

Dalam UU Perbankan No. 7 tahun 1992 kemudian direvisi menjadi UU Perbankan No. 10 tahun 1998 telah dijelaskan bahwa pembiayaan adalah penyediaan dana atau tagihan yang dipersamakan dengan itu. Antonio (2001:160) menjelaskan pembiayaan merupakan salah satu tugas pokok bank yaitu pemberi fasilitas dana untuk 
Falah, et al/Jurnal Ekonomi Syariah Teori dan Terapan Vol. 6 No. 6 Juni 2019: 1166-1177; ANALISIS PERBANDINGAN KINERJA PEMBIAYAAN BANK UMUM SYARIAH DAN BANK UMUM KONVENSIONAL DI INDONESIA PERIODE 2014-2017

memenuhi kebutuhan pihak-pihak yang membutuhkan dana.

Dari penjelasan di atas kinerja pembiayaan dapat diartikan sebaygai hasil atau prestasi dari usaha pemberian dana kepada pihak yang membutuhkan dana. Kinerja pembiayaan berguna dalam menentukan apakah pendanaan yang dilakukan sebuah lembaga atau organisasi kepada pihak deficit unit telah baik atau tidak.

\section{Non Performing Financing/Non performing} Loan

$$
\text { Non Performing Financing }
$$

merupakan pembiayaan bermasalah yang dilakukan oleh debitur pada suatu jenis pembiayaan tertentu akibat adanya kesengajaan atau faktor lain diluar kemampuan kendali debitur. Risiko kredit merupakan resiko yang paling serius bagi setiap lembaga keuangan. Risiko ini muncul dari ketidakmampuan debitur untuk menunaikan kewajibannya yang telah jatuh tempo berdasarkan kesepakatan. Risiko kredit yang terus berlanjut, tidak hanya akan menimbulkan kesulitan likuiditas, tetapi juga bisa menurunkan kualitas asset yang dimiliki oleh pihak bank (Chapra, 2008:75).

Menurut Mulyono (1995) NPF dalam BUS dapat dirumuskan sebagai berikut :

NPF $=$ Jumlah pembiayaan bermasalah $\times 100 \%$ Total pembiayaan

Dalam mengetahui Non Performing Loan pada BUK menggunakan rumus sebagai berikut:
NPL $=$ Jumlah Kredit Bermasalah $\times 100 \%$ Total Kredit

Berikut tabel yang menjelaskan mengenai kriteria dari penilaian peringkat terhadap NPF:

Tabel 2.

Kriteria Penilaian Peringkat NPF/NPL

\begin{tabular}{|c|c|}
\hline Peringkat & Nilai NPF \\
\hline 1 & $<2 \%$ \\
\hline 2 & $2 \% \leq \mathrm{NPF}<5 \%$ \\
\hline 3 & $8 \% \leq \mathrm{NPF}<8 \%$ \\
\hline 4 & $\mathrm{NPF} \geq 12 \%$ \\
\hline 5 & \\
\hline
\end{tabular}

Sumber: SE Bank Indonesia No.9/24/DPbS tahun 2007

Dari tabel 2.1 menjelaskan berapa persentase nilai NPF sehingga dikatakan sehat atau baik. Semakin rendah nilainya maka semakin baik perbankan tersebut. Financing to Deposit Ratio/Loan to Deposit Ratio

Basse dan Mulazid mengungkapkan risiko kredit kesehatan permodalan bank juga ikut dipengaruhi oleh tingkat likuiditas bank, dalam bank syariah dikenal sebagai Financing to Deposit Ratio (FDR). Rasio ini memberikan gambaran mengenai jumlah dana pihak ketiga yang disalurkan dalam bentukkredit/pembiayaan.

Berdasarkan Surat Edaran Bank Indonesia No.9/24/DPbS tanggal 30 Oktober 2007, rasio FDR dapat dirumuskan sebagai berikut: 
Falah, et al/Jurnal Ekonomi Syariah Teori dan Terapan Vol. 6 No. 6 Juni 2019: 1166-1177; ANALISIS PERBANDINGAN KINERJA PEMBIAYAAN BANK UMUM SYARIAH DAN BANK UMUM KONVENSIONAL DI INDONESIA PERIODE 2014-2017

Pembiayaan yang diberikan

$\mathrm{FDR}=$ $\mathrm{X} 100 \%$

Dana Pihak Ketiga (DPK)

LDR dapat dirumuskan sebagai berikut: LDR = Jumlah kredit yang disalurkan $x$ $100 \%$

Total deposit

Kriteria penilaian bank dapat dikatakan baik dlam pembiayaannya dapat dilihat pada tabel berikut:

Tabel 3.

Kriteria penilaian peringkat FDR/LDR

\begin{tabular}{|c|c|}
\hline Peringkat & Nilai LDR \\
\hline 1 & $50 \%<\mathrm{LDR} \leq 75 \%$ \\
\hline 2 & $75 \%<\mathrm{LDR} \leq 85 \%$ \\
\hline 3 & $\begin{array}{c}85 \%<\mathrm{LDR} \leq 100 \% \\
\text { atau LDR } \leq 50 \%\end{array}$ \\
\hline 4 & $100 \%<\mathrm{LDR} \leq 120 \%$ \\
\hline 5 & LDR $>120 \%$ \\
\hline
\end{tabular}

Sumber: SE Bank Indonesia NO.6//23/DPNP tahun 2004

\section{METODE PENELITIAN}

Penelitian ini merupakan penelitian kuantitatif. Menurut Suharso (2009: 3) penelitian kuantitatif adalah jenis kegiatan penelitian yang spesifikasinya adalah sistematis, terencana, dan terstruktur dengan jelas sejak awal hingga pembuatan desain penelitian, baik tentang tujuan penelitian, subjek penelitian, objek penelitian, sampel data, sumber data, maupun metodologinya.

Penelitian ini membandingkan non performing financing pada bank umum syariah dan non performing loan pada bank umum konvensional serta financing to deposit ratio pada bank umum syariah dan loan to deposit ratio pada bank umum konvesional pada periode 20132017. Penelitian ini menggunakan metode independent T-test. Teknik analisis data yang digunakan dalam penelitian ini adalah teknik statistik deskriptif dengan alat uji yang digunakan adalah uji beda $T$ test. Pemilihan uji beda $T$ test karena sampel yang digunakan dalam penelitian ini menggunakan rata-rata NPF dan FDR pada beberapa bank umum syariah serta NPL dan LDR bank umum konvensional.

Tabel 4.

\section{Daftar Sampel Bank Umum Syariah dan} Bank Umum Konvensional

\begin{tabular}{|l|l|}
\hline Bank Umum Syariah & Bank Umum Konvensional \\
\hline Bank Aceh Syariah & Bank ANZ Indonesia \\
\hline $\begin{array}{l}\text { Bank Muamalat } \\
\text { Indonesia }\end{array}$ & Bank INA Perdana \\
\hline Bank Victoria Syariah & Bank CCB Indonesia \\
\hline Bank BRI Syariah & BPD Papua \\
\hline Bank BNI Syariah & BPD Sumbar \\
\hline Bank Syariah Mandiri & Bank QNB Indonesia \\
\hline Bank Mega Syariah & Artha Graha Internasional \\
\hline $\begin{array}{l}\text { Bank Tabungan } \\
\text { Pensiunan Nasional } \\
\text { Syariah }\end{array}$ & Bank Commonwealth \\
\hline
\end{tabular}

Sumber: Laporan Keuangan Bank Umum Syariah dan Bank Umum Konvensional

\section{ANALISIS DATA DAN PENGUJIAN HIPOTESIS}

\section{Pengujian Asumsi}

\section{Normalitas}

Uji normalitas digunakan untuk menganalisis apakah distribusi pada variabel penelitian terdistribusi normal atau tidak. Jenis uji normalitas yang digunakan adalah pengujian Skewness Kurtosis. Jika data terbukti terdistribusi 
Falah, et al/Jurnal Ekonomi Syariah Teori dan Terapan Vol. 6 No. 6 Juni 2019: 1166-1177; ANALISIS PERBANDINGAN KINERJA PEMBIAYAAN BANK UMUM SYARIAH DAN BANK UMUM KONVENSIONAL DI INDONESIA PERIODE 2014-2017

normal maka dapat dilanjutkan pengujian independet t-test. Apabila data tidak terdistribusi secara normal selanjutnya akan dilakukan pengujian Mann Whitney (Latan (2014:312). Apabila dalam perhitungan diperoleh nilai signifikan $\geq 0,05$ maka data tersebut berdistribusi normal. Sebaliknya, jika nilai signifikan $\leq 0,05$ maka data tidak berdistribusi normal. Data berikut merupakan hasil pengujian Skewness Kurtosis.

Tabel 5.

Hasil Uji Normalitas

Skewness Kurtosis Normality Test

\begin{tabular}{|c|c|c|c|c|c|}
\hline Variabel & Obs & Skewness & Kurtois & $\begin{array}{c}\text { Adj } \\
\text { chi2 } \\
(2)\end{array}$ & Prob>chi2 \\
\hline NPL & 32 & 0.2310 & 0.6126 & 1.82 & 0.4022 \\
\hline LDR & 32 & 0.5936 & 0.9399 & 0.29 & 0.8648 \\
\hline NPF & 32 & 0.7691 & 0.0006 & 9.85 & 0.0073 \\
\hline FDR & 32 & 0.1136 & 0.8590 & 2.76 & 0.2521 \\
\hline
\end{tabular}

Sumber: Data diolah

Berdasarkan tabel 4.2 dapat dilihat bahwa nilai prob>chi2 pada variabel NPL sebesar 0.4022, variabel LDR 0.8648, variabel NPF 0.0073, variabel FDR 0.2521. sehingga data observasi pada penelitian ini telah menguji uji asumsi normalitas. Dari data diatas dapat diketahui yang terdistribusi normal adalah data pada variable NPL, LDR, FDR karena memiliki nilai prob>chi2 lebih dari 0.05, sedangkan data variabel NPF tidak terdistribusi normal karena memiliki nilai prob>chi2 kurang dari 0.05 .

\section{Pembuktian Hipotesis}

Pengujian ini digunakan untuk mengetahui apakah terdapat perbandingan antara variabel. Dikarenakan data pada salah satu variabel NPF/NPL pada bank umum syariah dan bank umum konvensional yang diuji tidak terdistribusi normal, maka pengujian ini menggunakan uji Mann Whitney. Uji Mann Whitney dipilih karena merupakan prosedur non-parametrik substitusi dari Indepent T-tes yang merupakan prosedur parametrik T-test (Latan, 2014:313). Berikut merupakan hasil dari Uji Mann Whitney pada NPF dan NPL.

Tabel 6.

Hasil Uji Mann Whitney

\begin{tabular}{|c|c|c|c|}
\hline Variable & Obs & $\begin{array}{c}\text { Rank } \\
\text { sum }\end{array}$ & Expected \\
\hline NPL & 32 & 963.5 & 1040 \\
\hline NPF & 32 & 1116.5 & 1040 \\
\hline Combined & 64 & 2080 & 2080 \\
\hline
\end{tabular}

Sumber: Data diolah

Ho: $(\mathrm{npl}==1)=(\mathrm{npf}==2)$

$$
z=-1.027
$$

Prob $>|z|=0.3043$

Dari hasil uji diatas menunjukkan bahwa probabilitas nilai sebesar 0.3043 atau lebih dari 0.05 yang artinya $\mathrm{H}_{0}$ diterima. Sehingga dapat disimpulkan bahwa tidak ada perbedaan atas ratarata NPF dan NPF.

Untuk FDR/LDR karena data yang telah diuji pada uji normalitas menemukan bahwa data terdistribusi normal. Maka dari itu pengujian ini menggunakan Independent T-test. Berikut merupakan 
Falah, et al/Jurnal Ekonomi Syariah Teori dan Terapan Vol. 6 No. 6 Juni 2019: 1166-1177; ANALISIS PERBANDINGAN KINERJA PEMBIAYAAN BANK UMUM SYARIAH DAN BANK UMUM KONVENSIONAL DI INDONESIA PERIODE 2014-2017

hasil dari uji Independent T-test pada FDR dan LDR.

Tabel 7.

Hasil Independent T-test

\begin{tabular}{|c|c|c|c|c|c|c|}
\hline $\begin{array}{l}\text { varia } \\
\text { ble }\end{array}$ & $\begin{array}{l}\mathrm{O} \\
\mathrm{bs}\end{array}$ & $\begin{array}{l}M \\
e \\
a \\
n\end{array}$ & $\begin{array}{l}\text { Std. } \\
\text { Err. }\end{array}$ & $\begin{array}{l}\text { St } \\
\text { d. } \\
\text { D } \\
\text { e } \\
\text { v. }\end{array}$ & $\begin{array}{c}95 \\
\% \\
\text { Co } \\
\text { nf. }\end{array}$ & $\begin{array}{l}\text { Inte } \\
\text { rval }\end{array}$ \\
\hline LDR & 32 & $\begin{array}{c}89.2615 \\
6\end{array}$ & $\begin{array}{l}1.65 \\
3796\end{array}$ & $\begin{array}{l}9.35 \\
5282\end{array}$ & $\begin{array}{l}85.8 \\
8862\end{array}$ & $\begin{array}{l}92.6 \\
345\end{array}$ \\
\hline FDR & 32 & $\begin{array}{c}88.4018 \\
8\end{array}$ & $\begin{array}{l}1.38 \\
4574\end{array}$ & $\begin{array}{l}7.83 \\
2336\end{array}$ & $\begin{array}{l}85.5 \\
7802\end{array}$ & $\begin{array}{l}11.2 \\
2573\end{array}$ \\
\hline $\begin{array}{l}\text { Comb } \\
\text { ined }\end{array}$ & 64 & $\begin{array}{c}88.8317 \\
2\end{array}$ & $\begin{array}{l}1.07 \\
1211\end{array}$ & $\begin{array}{l}8.56 \\
9691\end{array}$ & $\begin{array}{l}86.6 \\
9107\end{array}$ & $\begin{array}{l}90.9 \\
7236\end{array}$ \\
\hline Diff & & $\begin{array}{c}0.85968 \\
71\end{array}$ & $\begin{array}{l}2.15 \\
687\end{array}$ & & $\begin{array}{l}- \\
3.45 \\
1834\end{array}$ & $\begin{array}{l}5.17 \\
1208\end{array}$ \\
\hline
\end{tabular}

Sumber: Data diolah

Diff $=\operatorname{mean}(\mathrm{ldr}) \quad-\operatorname{mean}(\mathrm{fdr})$

$\dagger=0.3986$

Ho: diff $=0$ degrees of freedom $=62$

Ha: diff $<0$

Ha: diff $!=0$

Ha: diff $>0$

$$
\begin{array}{ll}
\operatorname{Pr}(T<t)= & 0.6542 \quad \operatorname{Pr}(|\mathrm{T}|>|\dagger|)= \\
0.6916 \quad \operatorname{Pr}(\mathrm{T}>\mathrm{t})=0.3458
\end{array}
$$

Dari hasil perhitungan data diatas menunjukkan bahwa nilai probabilitas $\operatorname{Pr}(T$ > t) adalah sebesar 0.3458, maka dapat disimpulkan bahwa nilai probabilitas hitung lebih dari 0,05 yang menunjukkan bahwa $\mathrm{HO}$ diterima atau $\mathrm{Ha}$ atau $\mathrm{H}_{1}$ ditolak. Artinya tidak terdapat perbedaan yang signifikan antara FDR dan LDR.

Uji normalitas digunakan untuk menganalisis apakah distribusi pada variabel penelitian terdistribusi normal atau tidak. Jenis uji normalitas yang digunakan adalah pengujian Skewness Kurtosis. Jika data terbukti terdistribusi normal maka dapat dilanjutkan pengujian independet t-test. Apabila data tidak terdistribusi secara normal selanjutnya akan dilakukan pengujian Mann Whitney (Latan (2014:312). Apabila dalam perhitungan diperoleh nilai signifikan $\geq 0,05$ maka data tersebut berdistribusi normal. Sebaliknya, jika nilai signifikan $\leq$ 0,05 maka data tidak berdistribusi normal. Data berikut merupakan hasil pengujian Skewness Kurtosis.

Tabel 8.

Hasil Uji Normalitas

Skewness Kurtosis Normality Test

\begin{tabular}{|l|l|l|l|l|l|}
\hline Variabel & Obs & Skewness & Kurtois & $\begin{array}{l}\text { Adj } \\
\text { chi2 } \\
(2)\end{array}$ & Prob>chi2 \\
\hline NPL & 32 & 0.2310 & 0.6126 & 1.82 & 0.4022 \\
\hline LDR & 32 & 0.5936 & 0.9399 & 0.29 & 0.8648 \\
\hline NPF & 32 & 0.7691 & 0.0006 & 9.85 & 0.0073 \\
\hline FDR & 32 & 0.1136 & 0.8590 & 2.76 & 0.2521 \\
\hline
\end{tabular}

Sumber: Data diolah

Berdasarkan tabel dapat dilihat bahwa nilai prob>chi2 pada variabel NPL sebesar 0.4022, variabel LDR 0.8648, variabel NPF 0.0073, variabel FDR 0.2521. sehingga data observasi pada penelitian ini telah menguji uji asumsi normalitas. Dari data diatas dapat diketahui yang terdistribusi normal adalah data pada variable NPL, LDR, FDR karena memiliki nilai prob>chi2 lebih dari 0.05, sedangkan data variabel NPF tidak terdistribusi normal karena memiliki nilai prob>chi2 kurang dari 0.05 .

Pengujian ini digunakan untuk mengetahui apakah terdapat 
Falah, et al/Jurnal Ekonomi Syariah Teori dan Terapan Vol. 6 No. 6 Juni 2019: 1166-1177; ANALISIS PERBANDINGAN KINERJA PEMBIAYAAN BANK UMUM SYARIAH DAN BANK UMUM KONVENSIONAL DI INDONESIA PERIODE 2014-2017

perbandingan antara variabel.

Dikarenakan data pada salah satu variabel NPF/NPL pada bank umum syariah dan bank umum konvensional yang diuji tidak terdistribusi normal, maka pengujian ini menggunakan uji Mann Whitney. Uji Mann Whitney dipilih karena merupakan prosedur non-parametrik substitusi dari Indepent T-tes yang merupakan prosedur parametrik T-test (Latah, 2014:313). Berikut merupakan hasil dari uji Mann Whitney pada NPF dan NPL.

Tabel 9.

Hasil Uji Mann Whitney

\begin{tabular}{|c|c|c|c|}
\hline Variable & Obs & $\begin{array}{c}\text { Rank } \\
\text { sum }\end{array}$ & Expected \\
\hline NPL & 32 & 963.5 & 1040 \\
\hline NPF & 32 & 1116.5 & 1040 \\
\hline Combined & 64 & 2080 & 2080 \\
\hline
\end{tabular}

Sumber: Data diolah

Ho: $(\mathrm{npl}==1)=(\mathrm{npf}==2)$

$$
z=-1.027
$$

$$
\text { Prob }>|z|=0.3043
$$

Dari hasil uji diatas menunjukkan bahwa probabilitas nilai sebesar 0.3043 atau lebih dari 0.05 yang artinya $\mathrm{H}_{0}$ diterima. Sehingga dapat disimpulkan bahwa tidak ada perbedaan atas ratarata NPF dan NPF.

Untuk FDR/LDR karena data yang telah diuji pada uji normalitas menemukan bahwa data terdistribusi normal. Maka dari itu pengujian ini menggunakan Independent T-test. Berikut merupakan hasil dari uji Independent T-test pada FDR dan LDR.
Tabel 10.

\begin{tabular}{|c|c|c|c|c|c|c|}
\hline $\begin{array}{l}\text { varia } \\
\text { ble }\end{array}$ & $\begin{array}{l}\mathrm{O} \\
\mathrm{bs}\end{array}$ & $\begin{array}{l}M \\
\mathrm{e} \\
\mathrm{a} \\
\mathrm{n}\end{array}$ & $\begin{array}{l}\text { Std. } \\
\text { Err. }\end{array}$ & $\begin{array}{l}\text { St } \\
\text { d. } \\
\text { D } \\
\text { e } \\
\text { v. }\end{array}$ & $\begin{array}{c}95 \\
\% \\
\text { Co } \\
\text { nf. }\end{array}$ & $\begin{array}{l}\text { Inte } \\
\text { rval }\end{array}$ \\
\hline LDR & 32 & $\begin{array}{c}89.2615 \\
6\end{array}$ & $\begin{array}{l}1.65 \\
3796\end{array}$ & $\begin{array}{l}9.35 \\
5282\end{array}$ & $\begin{array}{l}85.8 \\
8862\end{array}$ & $\begin{array}{l}92.6 \\
345\end{array}$ \\
\hline FDR & 32 & $\begin{array}{c}88.4018 \\
8\end{array}$ & $\begin{array}{l}1.38 \\
4574\end{array}$ & $\begin{array}{l}7.83 \\
2336\end{array}$ & $\begin{array}{l}85.5 \\
7802\end{array}$ & $\begin{array}{l}91.2 \\
2573\end{array}$ \\
\hline $\begin{array}{l}\text { Comb } \\
\text { ined }\end{array}$ & 64 & $\begin{array}{c}88.8317 \\
2\end{array}$ & $\begin{array}{l}1.07 \\
1211\end{array}$ & $\begin{array}{l}8.56 \\
9691\end{array}$ & $\begin{array}{l}86.6 \\
9107\end{array}$ & $\begin{array}{l}90.9 \\
7236\end{array}$ \\
\hline Diff & & $\begin{array}{c}0.85968 \\
71\end{array}$ & $\begin{array}{l}2.15 \\
687\end{array}$ & & $\begin{array}{l}- \\
3.45 \\
1834\end{array}$ & $\begin{array}{l}5.17 \\
1208\end{array}$ \\
\hline
\end{tabular}

Hasil Independent T-test

Sumber: Data diolah

$$
\begin{aligned}
& \text { diff }=\text { mean }(\mathrm{ldr})-\operatorname{mean}(\mathrm{fdr}) \\
& \dagger=0.3986 \\
& \text { Ho: } \text { diff }=0 \\
& \text { degrees of } \\
& \text { freedom }=62 \\
& \text { Ha: } \text { diff }<0 \\
& \text { Ha: diff } !=0
\end{aligned}
$$

Ha: diff $>0$

$$
\begin{array}{ll}
\operatorname{Pr}(\mathrm{T}<\mathrm{t})= & 0.6542 \quad \operatorname{Pr}(|\mathrm{T}|>|\mathrm{t}|)= \\
0.6916 \quad \operatorname{Pr}(\mathrm{T}>\mathrm{t})=0.3458
\end{array}
$$

Dari hasil perhitungan data diatas menunjukkan bahwa nilai probabilitas $\operatorname{Pr}(T$ > t) adalah sebesar 0.3458, maka dapat disimpulkan bahwa nilai probabilitas hitung lebih dari 0,05 yang menunjukkan bahwa $\mathrm{HO}$ diterima atau $\mathrm{Ha}$ atau $\mathrm{H}_{1}$ ditolak. Artinya tidak terdapat perbedaan yang signifikan antara FDR dan LDR.

\section{v. KESIMPULAN DAN SARAN}

\section{Kesimpulan}

Hasil pengolahan data dan pengujian pada hipotesis NPF/NPL menunjukkan bahwa tidak terdapat perbedaan yang signifikan. Hal ini menunjukkan kemampuan BUS dan BUK 
Falah, et al/Jurnal Ekonomi Syariah Teori dan Terapan Vol. 6 No. 6 Juni 2019: 1166-1177; ANALISIS PERBANDINGAN KINERJA PEMBIAYAAN BANK UMUM SYARIAH DAN BANK UMUM KONVENSIONAL DI INDONESIA PERIODE 2014-2017

dalam menangani resiko kredit atau ketidakmampuan nasabah dalam membayar kewajiban atau hutangnya dikatakan setara. Dapat diartikan untuk sekarang BUS dapat bersaing dengan BUK.

Begitu juga pada hasil pengolahan data dan pengujian pada hipotesis FDR/LDR menunjukkan bahwa tidak terdapat perbedaan yang signifikan. Ini menunjukkan bahwa kemampuan BUS dan BUK dalam memberi pembiayaan ataupun kredit kepada nasabah adalah sebanding. Rata-rata penyaluran dana bank kepada nasabah berada pada batas aman yaitu $88 \%$ yang dinilai sehat karena berada diantara $80 \%-110 \%$ sesuai standar dari Bank Indonesia. Dapat dikatakan bahwa pembiayaan sebagai motor penggerak perekonomian bekerja dengan baik.

\section{DAFTAR PUSTAKA}

Atmodjo , Rijanto Sastro, Skenario Rekapitalisasi Perbankan 1999-2001 , dalam Jurnal Hukum Bisnis vol. 6 tahun 1999

Antonio, muhammad Syafi'i. 2007. Bank Syariah Dari Teori ke Praktik. Gema Insani Press Jakarta.

Bank Indonesia. 1998. UU No.10 tahun 1998, Tentang Perubahan UU No. 7 1992 Tentang Perbankan, Jakarta

Basse dan Mulazid. 2017. Analisa Pengaruh Kualitas Aset, Likuiditas, Efensiensi Usaha dan Profitabilitas terhadap Rasio Kecukupan Modal pada Bank Umum Syariah Periode 2012-2015

Chapra, M. Umer \& Habib Ahmed, Coorporate Governance Lembaga Kevangan Syariah, Jakarta : P.T Bumi Aksara, 2008.

Heri Sudarsono, Bank dan Lembaga Keuangan Syariah, EKONISA Kampus Fakultas Ekonomi UII Yogyakarta, 2003

Kasmir. (2011). Analisis Laporan Keuangan: Jakarta : PT Raja Grafindo Persada.

Latan, Hengky. 2014. Aplikasi Analisis Data Statistik Untuk IImu Sosial Sains dengan IBM SPSS.Bandung: Alfabeta

Mulyono, Teguh P. 1995. Aplikasi Akuntansi Manajemen dalam Praktek Edisi ke 2, BPFE. Yogyakarta.

Otoritas Jasa Keuangan. 2018. Data BUS dan BUK

Ridwan. 2005. Manajemen Baitul Maal Wa Tamwil (BMT). Yogyakrta: Ull. Press

Rindawati, Erna 2007, 'Analisis Perbandingan Kinerja Keuangan Perbankan Syariah dengan Perbankan Konvensional', Yogyakarta

Rivai, Veithzal dan Ismail, Rifki. 2013. Islamic Risk Management for Islamic Bank. Jakarta. PT Gramedia Pustaka Utama

Suharso Puguh, 2009. Metode Penelitian Kuantitatif unuk Bisnis. Jakarta: PT. Remaja Rosida Karya.

Surat Edaran Bank Indonesia NO.6//23/DPNP tahun 2004 
Falah, et al/Jurnal Ekonomi Syariah Teori dan Terapan Vol. 6 No. 6 Juni 2019: 1166-1177; ANALISIS PERBANDINGAN KINERJA PEMBIAYAAN BANK UMUM SYARIAH DAN BANK UMUM KONVENSIONAL DI INDONESIA PERIODE 2014-2017

Surat Edaran Bank Indonesia No.9/24/DPbS tahun 2007

Tangkilisan, Nogi Hessel. 2005. Manajemen

Publik. Jakarta. PT. Gramedia

Widiasarana Indonesia

Undang-Undang No. 21 Tahun 2008,

Tentang Perbankan Syariah

Wibowo. 2007. Manajemen Kinerja. PT. Raja Grafindo Parsada: Jakarta. 